\title{
Investigating the Effect of Relational Marketing Tactics on Customer's Loyalty of e-Banking Services in Terms of Customer of Bank Tejarat
}

\author{
Hadi Nezari* \\ Leila Nazari** \\ Mousa Ahmadi** \\ * MA Student in Marketing Management, Abhar Branch, Islamic Azad University of Abhar, Iran \\ ${ }^{\star *}$ Assistant Professor, Department of Marketing Management, Abhar Branch, Islamic Azad University of Abhar, Iran
}

\section{Doi:10.5901/mjss.2016.v7n2s2p133}

\begin{abstract}
The aim of this study was to evaluate the effect of relational marketing tactics on customer loyalty of e-banking services from the perspective of bank Tejarat customers. A total of 384 customers of electronic services of Tejarat bank branches in Tehran were selected as sample. The main instrument used in this study was a questionnaire for the purpose Ndubisi and Wah marketing standard questionnaire (2005) with reliability 0.95 and loyalty questionnaire Koksal and Doma (2014) with a reliability of 0.82 was used. Finally, the raw data obtained are analyzed using SPSS statistical software was used. The results showed that the correlation for each of the variables of trust, communication, conflict management and competence in order of 0.317 , $0.370,0.637$ and 0.562 , which suggests that customers of e-service of Tejarat bank branches in Tehran, conflict management and competence variables than others had the strongest relationship with loyalty and trust and communication variables has poorer relationships with their loyalty. Finally, according to the results of the descriptive statistics of the variables showed that Tejarat bank branches in Tehran in terms of relationship marketing are already in a relatively good position to take over.
\end{abstract}

Keywords: relational marketing, loyalty, commercial bank, trust, communication, conflict management, competency

\section{Introduction}

The current era of accelerating change and unpredictable and organizations due to factors such as the uncertain boundaries between markets, more fragmented markets, shorter product life cycle, rapid changes in purchasing patterns of customers and more informed and more sophisticated customers, with the most difficult competitive situation that has never before faced (Wong and shoal, 2002). In this regard only organizations in the field of competition will have good relations with the main focus of their activities met needs of their customers and satisfying their needs. The banking system of the country (as the most important pillar of the economy) has no exception to this principle and requires the customer as a strategy to maintain the loyalty of existing customers to apply.

In fact, maintain an ongoing relationship with the customer is the only way that banks use a defensive strategy and will maintain its current customers have to pass it (Colgate and Alexander, 1998).

With the advent of Internet banking, a new generation of customers came into being. Banks in order to achieve a greater share of the profit competitive market should attract more than a generation and customer loyalty (Abkenar, 2013). In the meantime, increasing customer awareness and access to information about the market and has led to lower customer loyalty (Ndubisi et al, 2007); Also on the other hand, research shows that the cost of attracting new customers is 5 times more than the cost of retaining existing customers due to the maintenance of the old customers that is more important than attracting new customers. In fact, consumer loyalty is to support organizations and organizations can have better control over applications (wang et al, 2001). To achieve this, marketing transactions that has only focuses on the concepts of business attraction and retention of customer care does not work (Gummesson, 1999); therefore, today introduced the new concept of marketing to relationship marketing as an alternative, communication with the customer fills the vacuum. Relationship marketing as a part of search marketing strategies to attract and retain customers by providing quality services and therefore it is one of the keys to success in the rapidly changing market has become (Andaleeb, 1996).

Relationship marketing tactics are practical ways to implement relational marketing (Tseng, 2007) and through marketing tactics, trying to create an effective communication are customer-oriented, to be the company have attracted customers, keep them loyal. In recent decades, both in the field of relationship marketing and the scientific community 
has been highly regarded in the field of action (Egan, 2011). Tseng (2007) a variety of marketing tactics increase the quality of relationship between specific industry and customer. Four types of relationship marketing tactics including direct mail to customers, tangible rewards, interpersonal communication and attention to customer's individual needs, with the aim, according to subjective perceptions proposal considered. Also Bansal (2005), to a group of relational marketing tactics, and pointed out that the quality, satisfaction, value, trust, competence, communication, conflict management, price perception, commitment, attractiveness of alternatives, the attitude toward switching, norms mental, switching costs, switching previous experiences and a variety of search methods to retain their customers. According to what was said, it becomes clear that the concept of relationship marketing based on the different needs of customers, their preferences, purchase behavior and price sensitivity, the phenomenon has become crucial in the business world. Moreover, because of exposure to today's highly competitive environment in the banking industry, the use of relationship marketing concepts, retain customers and create loyalty through them, can lead to increased market share, profitability and cost reduction (Rizan et al., 2014). So banks can use relationship marketing means understanding the wants and needs of customers and create long-term relationships with them to create customer loyalty and engage loyal customers also benefit from the advantages (Abdullah et al., 2014). It is important to know that in today's time it becomes clear that the number of private banks and financial and credit institutions with state-owned banks rise and increased intensity of competition is more than ever, the profitability of that could give rise loyal customers.

Due to problems such as low customer loyalty, loss of customers, lower working capital, despite complaints from dissatisfied customers and increase customer loyalty and relationship marketing seems techniques in the field of Tejarat bank branches ignored, and in the organization of the customer and enhance customer loyalty in the corporate rhetoric and the practical level, this task will not be considered. According to this study investigate the relationship between relationship marketing and customer loyalty electronic services in the Bank Tejarat. In this regard, the following hypotheses are proposed:

First hypothesis: there is a significant relationship between the trust and customer's loyalty of e-service at the Tejarat bank.

The second hypothesis: there is a significant relationship between the communications with customer's loyalty of eservice at the Tejarat bank.

The third hypothesis: there is a significant relationship between the conflict management with customer's loyalty of e-service at the Tejarat bank.

The fourth hypothesis: there is a significant relationship between the competencies of customer customer's loyalty of e-service at the Tejarat bank.

\section{Methodology}

This study is a quantitative approach. This study based on purpose is applied and nature is descriptive-correlation research; because the descriptive picture of the status of Tejarat Bank offers and solidarity in order that the relationship between the dependent variable (customer loyalty) and independent variables (trust, communication, conflict management and competence) country. The population of this study to all customers with electronic services in Tehran Tejarat bank branches that make up the inquiries of management on the basis of Tejarat bank branches in Tehran, found the number, more than 100 thousand people are included, considering that the population size is unlimited, according to Morgan table and, 384 customers electronic services in Tehran Tejarat bank branches were selected randomly as the sample. To gather information about the standard variables from the questionnaire as the research tool was used to measure so that the variable "relational marketing" questionnaire Ndubisi and Wah (2005) was used. The questionnaire included four subscales of "trust", "communication", "and conflict management" and "merit". The variable to measure the "loyalty" of the questionnaire designed by Koksal and Doma (2014) was used (Table 1).

Table 1: The research questionnaire

\begin{tabular}{llcc}
\hline Variable & Subscales & The number of questions & Reliability \\
\hline \multirow{4}{*}{ Relational marketing } & Confidence & 5 & 0.78 \\
& Communications & 5 & 0.82 \\
& Conflict Management & 5 & 0.81 \\
Loyalty & Competence & 5 & 0.81 \\
\hline
\end{tabular}

Source: Findings 
Finally, after collecting data, analyzing all the data using SPSS software were used. Descriptive and inferential statistics were used for data analysis. In descriptive statistics, using indicators, mean, standard deviation and coefficient of variation, to ratings and reviews the importance of the case from the perspective of customer relationship marketing tactics were studied and analyzed in order to test the hypothesis and analysis accepting or rejecting them, Pearson correlation analysis was used.

\section{Data Analyze}

In this section, the results are compiled and analyzed data based on statistical inference and carried out using appropriate statistical techniques, in order to confirm or refute the hypothesis presented. Information collected by applying appropriate statistical tests, according to the hypothesis, was analyzed. The demographic characteristics offered descriptive and inferential statistics variables are finally using the authenticity of the hypothesis determined.

\subsection{Descriptive statistics}

Results of average scores provided by customers for each of relationship marketing tactics study are presented in Table 2:

Table 2: Total scores of relational marketing tactics from the perspective of e-service customer at Tejarat Bank

\begin{tabular}{lcccc}
\hline Variable & Average & Standard deviation & Coefficient of variation & Rank Importance \\
\hline Confidence & 4.20 & 0.64 & 0.152 & 1 \\
Communications & 4.25 & 0.67 & 0.158 & 2 \\
Conflict Management & 3.97 & 0.69 & 0.174 & 3 \\
Competence & 3.97 & 0.79 & 0.199 & 4 \\
\hline
\end{tabular}

Source: Findings

The results presented in Table 2 show the mean scores provided by customers for each of relational marketing tactics. According to the scores mean, standard deviation and coefficient of variation is observed that Tejarat bank in terms of customer service, the trust is most important and least important to have merit.

\subsection{Inferential statistics}

In this section with respect to variables, hypotheses are tested using Spearman correlation. The results of the correlation coefficient between the commitment of relational marketing tactics and loyalty of in the table (3) provided:

Table 3: Correlation between the trust and loyalty

\begin{tabular}{lccc}
\hline Independent variable & Correlation & The correlation coefficient & The significance level \\
\hline Confidence & Spearman & ${ }^{* *} 0.317$ & 0.001 \\
Communications & Spearman & ${ }^{* *} 0.370$ & 0.001 \\
Conflict Management & Spearman & ${ }^{* *} 0.637$ & 0.001 \\
Competence & Spearman & ${ }^{* *} 0.562$ & 0.001 \\
\hline
\end{tabular}

Source: Findings

As shown in Table 3 it becomes clear that there is a significant positive relationship between the marketing tactics outlined in the study of trust, communication, conflict management and the competence, loyalty to the surface $(p<0.001)$. This means that by upgrading any of these tactics, as well as increase customer loyalty.

\section{Conclusion}

The first hypothesis test showed that there is a good correlation between trust and customer loyalty that was consistent 
with the results of Ndubisi (2007) and Ndubisi and Wah (2005) and Granmayeh Yeganeh (2007); these results suggest that there is a relationship between marketing successes requires confidence and commitment in the relationship. The formation of trust in the relationship ensures a level of confidence in the integrity promise opponent by any of the parties. So you have such confidence in the parties (especially for the client) to be provided, leads to satisfaction and as a result will have to continue his collaboration with the Bank. Other results indicate a strong relationship between customer loyalty and associations in accordance with and in line with the findings of researchers such as Jersey and et al. (2013), alRubaie (2010), Ranjbarian and Barari (2009) and Alipur and Gholami (2010), respectively. These findings suggest that the proper connections may provide more customers' loyalty that makes such an outcome was not unexpected. Because if done correctly so that communications objectives, expectations and standards to meet customer expectations, compared with other competitors have greater value customer preferred to continue working with the diagnosis and the possibility to win more loyal customers to the bank.

The third hypothesis of this study also showed that conflict management and there is a significant positive relationship with customer loyalty similar to the findings of researchers like Ndubisi (2007) and Gilani Nia and Sharif (2010). It should be noted that the existence of such a relationship could be due to a proper understanding of the parties regarding the objectives and their role, leading to increased customer loyalty, because conflict management before the problems lead to the ability of the negative consequences of minimize and the obvious potential conflict points. The latest findings of the study indicate a positive relationship between competence and loyalty of customers who arrived with the findings of researchers like Wared and Daguerre (2007), Ndubisi and Wah (2005) and Ranjbarian and Barari (2009) was adapted.

There is good correlation between competence and loyalty of clients shows that customer perception of the skill, ability and knowledge required for effective performance impact on the other side its loyalty. Because in this case the customer is the organization and those who cooperate with it, the market-related competence, merit associated with managing the relationship and its other merits, as a result to continue to work with it.

\section{Conclusion}

According to a literature review and what the results of the present study was to analyze the raw data, it was found that the dimensions of relationship marketing, trust and communication than others and most important aspects of conflict management and competence then rank the next order. It also becomes clear that the correlation for each of the variables of trust, communication, conflict management and competence in order of $0.317,0.370,0.637$ and 0.562 , which suggests that customers e-service at Tejarat Bank branches in Tehran, conflict management and competence variables than others had the strongest relationship with loyalty and trust and communication variables has poorer relationships with their loyalty. Finally, according to the results of the descriptive statistics of the variables showed that the Tejarat bank branches in Tehran in terms of relationship marketing are already in a relatively good position to take over.

\section{Research Proposals}

- It is recommended that research be done in the wider community and with larger sample size.

- It is recommended that research be done on the customers of other banks.

- It is recommended that this research be conducted in other regions and other provinces and the results evaluated.

- It is recommended other relationship marketing tactics examined in future research.

\section{References}

Abkenar, Sayad. Peidaee, Mohammad. Asli Zadeh, Amin. (2013). Factors affecting customer loyalty Commerce Bank in Tehran. Journal of Information Technology Management Faculty of Tehran University Volume 5, Issue 2. P 23-36.

Ranjbarian, B., Barari, Mojtaba. (2009). Relationship marketing approach to improve customer satisfaction. Journal of executive management, issue 2, pp 82-63.

Alipur, HR., Gholami, Mona. (2010). The impact of relationship marketing on customer loyalty. Master Thesis, Rasht Islamic Azad University, Faculty of Humanities.

Granmayeh Yeganeh, Ciros. (2007). Review and assess the factors affecting customer loyalty based on the effective area of banking services (Case Study: the New Economy Bank), Master's Thesis, School of Management, University martyr Beheshti, p. 54.

Gilani Nia, Sh., Sharif, Bahram. (2010). The impact on customer loyalty and relationship marketing. Master Thesis Islamic Azad University, Faculty of Humanities. 
Abdullah, M.F., Putit, L., Teo, C.B.C. (2014). Impact of Relationship Marketing Tactics (RMT's) \& Relationship Quality on Customer Loyalty: A Study within the Malaysian Mobile Telecommunication Industry. Procedia - Social and Behavioral Sciences 130, 371 378.

Alrubaiee, L. (2010). Investigate the Impact of Relationship Marketing Orientation on Customer Loyalty: The Customer's Perspective. International Journal of Marketing Studies, Vol. 2, No. 1; pp: 155-173.

Andaleeb, SS. (1996). An Experimental Investigation of Satisfaction and Commitment in Marketing Channels: The Role of Trust and Dependence, Journal of Retailing 72(1):7793.

Bansal, H. S., Taylor, S. F., \& James, Y. S. (2005). "Migrating" to New Service Providers: Toward a Unifying Framework of Consumers' Switching Behaviors. Journal of the Academy of Marketing Science, 33(1), 96-115.

Colgate, M. and Alexander, N. (1998)." Banks relationship and their customer: Arelationship marketing perpective". International Journal of bank marketing.

Egan, J. (2011). Relationship Marketing: Exploring Relational Strategies in Marketing, Harlow, FT/Pearson Education Publication.

Gummesson, E. (1999), 'Total Relationship Marketing - Rethinking Marketing Management: From 4PS To 30S,' Butterworth: Heinermann.

Jesri, P., Ahmadi, F., Fatehipoor, M. (2013). Effects of Relationship Marketing (RM) on Customer Loyalty (Case Study: Mehr Bank, Kermanshah Province, Iran). interdisciplinary journal of contemporary research in business, vol 4, no 11, pp: 304-312.

Ndubisi, N. O and Wah, C. K. (2005) «Factorial and discriminant analyses of the underpinning of relationship marketing and customer satisfaction», International Journal of bank marketing, Vol. 23, No. 7, pp. 542.

Ndubisi, N. O. (2007) «Relationship marketing and customer loyalty», Marketing Intelligence \& Planning, Vol. 25, No. 1, pp. 98-106.

Rizan, M., Warokka, A., and Listyawati, D. (2014). "Relationship Marketing and Customer Loyalty: Do Customer Satisfaction and Customer Trust Really Serve as Intervening Variables? ", Journal of Marketing Research and Case Studies, Vol. 2014 (2014), Article ID 724178, DOI: 10.2014.5171.724178.

Tseng, YM., (2007). The Impacts of Relationship Marketing Tactics on Relationship Quality in Service Industry. The Business Review 7 (2): 310314.

Wang, Y.-S., T.-I. Tang, and J.-T.E. Tang, "An Instrument for Measuring Customer Satisfaction Toward Web Sites That Market Digital Products and Services," Journal of Electronic Commerce Research, Vol. 2, No. 3:89-102, 2001.

Ward, T., Dagger, T. S. (2007). The complexity of relationship marketing for service customers. Journal of Services Marketing, 21(4), 281-290.

Wong, A.and shohal, A. (2002). "An examination of the relationship between trust, commitment and relationship quality", International Journal of retail \& Distribution Management, Vol.30, No.1, pp.34-50. 